\title{
A MANCHA ENQUANTO CONTRASTE: PORTUGAL VERSUS SUAS EX-COLÔNIAS EM ÁFRICA NAS NARRATIVAS DE ISABELA FIGUEIREDO E DULCE MARIA CARDOSO
}

\author{
THE STAIN AS A CONTRAST: PORTUGAL \\ VERSUS ITS EX-COLONIES IN AFRICA IN THE \\ NARRATIVES OF ISABELA FIGUEIREDO \\ AND DULCE MARIA CARDOSO
}

\author{
Larissa Fonseca e Silva ${ }^{1}$ \\ Eliana da Conceição Tolentino ${ }^{2}$
}

\section{RESUMO}

Neste artigo, pretende-se apontar como, no livro Caderno de memórias coloniais, de Isabela Figueiredo, e em O Retorno, de Dulce Maria Cardoso, a representação da mancha (das roupas e das mãos) aparece simbolizando ora liberdade, ora culpa - sempre endossando, porém, um contraste entre a sociedade portuguesa e a vida que as autoras tinham em Moçambique e Angola, respectivamente.

PALAVRAS-CHAVE: Mancha. Retornados. Descolonização.

\section{ABSTRACT}

In this article, we intend to demonstrate how, in the book Caderno de memórias coloniais, by Isabela Figueiredo, and in $O$ retorno, by Dulce Maria Cardoso, the representation of the stain appears sometimes symbolizing freedom, sometimes shame - always reinforcing, however, a contrast between the Portuguese society and the life that the authors had in Mozambique and Angola, respectively.

KEYWORDS: Stain. Retornados. Decolonization. 


\section{INTRODUÇÃO}

A Revolução dos Cravos, em 1974, acelerou o processo de descolonização do que o Estado Novo português chamava de "províncias ultramarinas" em África: Angola, Moçambique, Guiné-Bissau, Cabo Verde e São Tomé e Príncipe. Com a emancipação desses países, os ex-colonos portugueses se viram, após as guerras de libertação, em meio às guerras civis dos partidos que disputavam o poder, tornando-se alvo fácil de retaliação dos revolucionários de qualquer partido. Com isso, solicitando ajuda internacional, deixaram, aos milhares, as terras que tinham adotado como pátria. Muitos tinham nascido em Portugal, tendo ido para o continente africano por incentivo do governo salazarista; assim, quando precisaram se refugiar, voltando a Portugal, eles e seus filhos foram chamados "retornados".

Dulce Maria Cardoso, portuguesa cuja infância foi passada em Angola, e Isabela Figueiredo, que nasceu e cresceu em Moçambique, são autoras contemporâneas sempre lembradas quando se discute a questão dos retornados. "Questão", aqui, tem seu uso justificado também pela indecidibilidade dessa situação de não lugar / não estar (TOLENTINO, 2017, p. 6052), isto é, a sensação de ambiguidade inerente aos exilados, conforme aponta Edward Said (2003) no ensaio "Reflexões sobre o exílio":

A maioria das pessoas tem consciência de uma cultura, um cenário, um país; os exilados têm consciência de pelo menos dois desses aspectos, e essa pluralidade de visão dá origem a uma consciência de dimensões simultâneas, uma consciência que para tomar emprestada uma palavra da música - é contrapontística (SAID, 2003, p. 59).

A própria denominação em si, "retornados", já traz essa marcação das "dimensões simultâneas" (SAID, 2003, p. 59), uma vez que "retornar" pressupõe, igualmente, um lugar original e um lugar ao qual se foi. Vale ressaltar, porém: ainda que Said (2003, p. 54) concorde que a denominação "exilado" caiba a todo aquele que é impedido de voltar para sua pátria, ele faz uma distinção entre expatriado, emigrado, exilado e refugiado. As duas primeiras definições implicariam, em diferentes níveis, alguma possibilidade de escolha. Exílio estaria mais ligado a um banimento, geralmente individual. Os refugiados, por sua vez, seriam frutos das políticas do século XX: "A palavra 'refugiado' [...] sugere grandes rebanhos de gente inocente e desnorteada que precisa de ajuda internacional urgente" (SAID, 2003, p. 54). Os retornados, por essa classificação mais estrita, seriam, pois, refugiados. Entretanto, conforme aponta Elsa Peralta em “O testemunho do 'retorno': deslocamento, história ilegítima, desidentificação”,

[...] a lei não lhes concedeu esse estatuto, já que o representante do Alto Comissariado das Nações Unidas para os Refugiados (ACNUR) em Portugal e o governo português na altura, entenderam que esses migrantes não atravessaram uma fronteira internacional, mas movimentavam-se dentro 
de um espaço imperial em declínio como cidadãos do país de destino e, portanto, não podiam ser considerados refugiados em termos da Convenção dos Refugiados de 1951 (Kalter 2017) (PERALTA, 2018, p. 148).

Apesar do que dizia a lei, muitos retornados preferiam a definição de "refugiados" (PERALTA, 2018, p. 148), afinal:

"Refugiado" e "retornado" são dois conceitos opostos de pertença, com diferentes cargas emocionais, que ainda aguardam integração do ponto de vista identitário. Nomear estas pessoas enquanto "retornados" - e não como refugiados das guerras civis entre os movimentos de libertação - é classificá-las na sua condição transitiva - de colono - beneficiária da doutrina do Salazarismo e do sistema colonial, assim retirando-a do quadro mais vasto do colapso do domínio colonial europeu em África eclodido desde os anos cinquenta. Se são "retornados", regressaram à sua terra natal como ex-colonos de um território que ocupavam e exploravam, colando-lhes para sempre à pele uma mácula: a mácula da vergonha, de quem sendo desterrado, não é vítima da violência que provocou o desterro, mas antes seu perpetrador. Se são "refugiados", foram arrancados de casa, vítimas de eventos sobre os quais não tinham controlo, tendo, por isso, o direito de ver o seu sofrimento reconhecido. Mas a lei não lhes permitiu esse estatuto e história não lhes concedeu essa absolvição (PERALTA, 2018, p. 148-149).

"Retornado" tornou-se, pois, um termo pejorativo, uma vez que, para muitos portugueses que não saíram de Portugal, qualquer retornado era "explorador dos negros africanos" (cf. CARDOSO, 2013, p. 129; FIGUEIREDO, 2018, p. 136; PERALTA, 2018, p. 147), gerando neles a "mácula da vergonha" sobre a qual se refere Elsa Peralta (2018, p. 149). Para completar, posto que vinham aos milhares, os retornados eram vistos ainda como ameaça ao sistema econômico-social português, frágil naquele momento. Os que não tiveram condições financeiras para exportar seus bens em caixotes antes que as guerras civis acirrassem, voltaram, afinal, praticamente sem nada. Assim, essa vergonha também é pela condição financeira em que estavam, como explica Dulce Cardoso em entrevista concedida a Alleid Ribeiro Machado:

[...] era uma altura em que não ter casa era uma indignidade, e uma casa é, digamos, o reduto mínimo da dignidade. Os que ficaram em hotéis eram mal vistos inclusive entre os próprios retornados. Eu fiquei em um hotel por dois anos, no Estoril [...]. E eu também estava, a quando nada, a nunca ter voz. Quer o nível social de meus pais, quer toda a minha experiência seria no sentido de perder, como os meus colegas, ou que não estudaram, ou que se envolveram com drogas e, mais tarde, morreram por overdose, ou como os que sobreviveram, que se tornaram balconistas, ou estão casados e têm muitos filhos, muitos problemas. Ninguém pensa sobre isso. E não 
é estranho que durante 30 anos ninguém tenha falado sobre isso e aposto que, mesmo daqui a 30 anos, continuarão não falando, porque não vai haver quem queira. Há uma elite que não passou por isto e quem é que fala? Quem é que tem voz? (CARDOSO, 2014, p. 118).

\section{CADERNO DE MEMÓRIAS COLONIAIS E O RETORNO}

Os livros das duas autoras trazem, devido ao tema, muitas semelhanças entre si. De certa forma, por exemplo, ambos são livros de formação, ainda que Isabela Figueiredo não tenha optado por formas convencionais de "romance". Para escrever Caderno de memórias coloniais, a escritora parte dos registros que colecionara em seu blogue $\mathrm{e}^{3}$ durante alguns anos, todos com caráter de diário. Assim, é sobre seu passado que escreve, mas ela tem consciência de que lembrar é também ficcionalizar: "Pode esperar-se que os factos relatados correspondam ao que foi testemunhado, vivido e sentido, não que sejam um relato literal isento de trabalho literário" (FIGUEIREDO, 2018, p. 10). É como escreve Wander de Melo Miranda (1992) em “A ilusão autobiográfica" 4 :

A autobiografia, mesmo se limitada a uma pura narração, é sempre uma autointerpretação, sendo o estilo o índice não só da relação entre aquele que escreve e seu próprio passado, mas também o do projeto de uma maneira de dar-se a conhecer ao outro, o que não impede o risco permanente do deslizamento da autobiografia para o campo ficcional, o seu revestir-se da mais livre invenção. Apesar do aval de sinceridade, o conteúdo da narração autobiográfica pode perder-se na ficção, sem que nenhuma marca decisiva revele, de modo absoluto, essa passagem, porquanto a qualidade original do estilo, ao privilegiar o ato de escrever, parece favorecer mais o caráter arbitrário da narração que a fidelidade estrita à reminiscência ou o caráter documental do narrado (MIRANDA, 1992, p. 30).

Em suma, ainda que Isabela Figueiredo escreva sobre si, e coloque fotos pessoais que têm como função comprovar a veracidade daquilo que viveu, ela se afasta do texto que é, também, ficcionalização. Como se vê no prefácio do Caderno, a autora se afasta da personagem ao usar a terceira pessoa escrevendo a "história de uma menina" (FIGUEIREDO, 2018, p. 8):

O Caderno de memórias coloniais relata a história de uma menina a caminho da adolescência, que viveu essa fase da vida no período tumultuoso do final do Império colonial português. O cenário é a cidade de Lourenço Marques, hoje Maputo, espaço no qual se movem as duas personagens em luta: pai e filha. São símbolos de um velho e de um novo poder; de um velho mundo que chegou ao fim, confrontado por uma nova era que desponta e exige explicações. A guerra dos mundos em 1970 (FIGUEIREDO, 2018, p. 8-9). 
Ela também se refere ao pai como personagem: "Ao longo destes anos, tenho assumido a missão de proteger a personagem do meu pai da fácil e tentadora diabolização que sobre ela é possível desenhar" (FIGUEIREDO, 2018, p. 11).

O retorno, de Dulce Maria Cardoso, não é explicitamente baseado em memórias da autora, mas, quando perguntada sobre a parcela de realidade/ experiência no livro, na entrevista concedida a Alleid Ribeiro, ela responde:

[...] eu digo sempre, em relação à ficção, que é necessário inventar uma mentira para contar uma verdade. Eu acho que a verdade, na maior parte dos casos, é longa, é maçadora, é monótona, e não se consegue ir a lado nenhum contando a verdade. E por isso a grande vantagem da ficção (CARDOSO, 2014, p. 105).

Em $O$ retorno, temos a narração de um adolescente, Rui, que é obrigado a deixar Angola devido à retaliação cada vez mais violenta contra os ex-colonos. Sobre Rui, diz Cardoso:

Houve de fato um Rui real que não tem nada a ver com o Rui do livro. Houve um Rui real, que perdeu os irmãos, que foram assassinados. E escolher uma personagem masculina $\mathrm{e}$ chamá-la de Rui no livro foi uma forma de homenagem, não só àquele Rui, mas ao que aquele Rui representava. Pronto, há sempre brincadeiras, por exemplo, a Maria da Guia ${ }^{5}$ que é a empregada. Houve mesmo uma empregada de uma vizinha, que eu nunca a conheci sequer, mas que eu sempre escutava a chamarem por Maria da Guia. Há brincadeiras em que eu sei porque aquela personagem é assim, ou de outro jeito. Mas só eu faço parte do real. Só eu sou a personagem real (risos). Há contos em que eu sou mesmo a personagem, em que eu estou lá. Agora, por exemplo, estou a acabar uns contos para a Bélgica e para a Holanda e eu sou eu através das personagens, mesmo a Dulce escritora. A única que é real (CARDOSO, 2014, p. 98).

Assim, Dulce Cardoso toma a personagem Rui para se inserir no livro, enquanto Isabela Figueiredo escreve em primeira pessoa e refere a si mesma, no prefácio, como personagem. Na proposta de leitura deste artigo, porém, optamos por chamar de "Isabela Figueiredo" a autora, a narradora e a personagem.

Em Caderno de memórias coloniais, segundo Isabela Figueiredo, a menina Isabela já teria, desde muito cedo, percebido a desigualdade social e o racismo na capital Maputo que, então, tinha nome português: Lourenço Marques. Em O retorno, por outro lado, o adolescente Rui tem uma visão mais ingênua sobre o que está acontecendo em Angola e reproduz muito dos discursos racistas do pai, ainda que não se perceba como tal. 
A figura do pai é forte em ambos os enredos, sendo fruto - e símbolo - do Império e do colonialismo. Nos dois enredos cabe a descrição paterna feita por Isabela Figueiredo em Caderno de memórias coloniais: “[...] um homem de um tempo, no seu contexto, tão racista como os que eram racistas, e eram muitos, na metrópole e no ultramar" (FIGUEIREDO, 2018, p. 11).

Em O retorno, o pai é a ausência. O pai, que ficou em Angola, desaparecido, enquanto Rui e a família precisaram se refugiar em Portugal, está intimamente ligado à ideia da pátria que deixou de sê-la. Como diz a própria Dulce Maria Cardoso na entrevista a Alleid Machado:

[...] Eu [...] fiz uma versão [d'O retorno], em que o pai vinha com eles e eu percebi que desta forma ninguém iria conseguir relacionar a perda, porque ninguém consegue perceber o que é perder um país. O que é perder um país? Normalmente as pessoas não perdem um país. Agora perder um pai, ou a Pirata ${ }^{6}$, deixar um pai para trás, haveria mais gente. Portanto, tem que se inventar. Nada daquilo aconteceu de fato, eu nunca tive um cão em Angola. Aquilo que as pessoas mais se identificam eu nunca vi se quer, nunca tive acesso. Agora, eu tive acesso ao resto todo, a perda, a ela própria (CARDOSO, 2014, p. 105).

Em Caderno de memórias coloniais, por sua vez, o pai é a presença constante da culpa. A narradora se culpa por amá-lo e, simultaneamente, odiá-lo. Culpa-se por lhe ser cúmplice e algoz: ela viveu e foi parte do colonialismo; ela soube, porém, compreender a injustiça desse sistema e rechaçá-lo. Denunciá-lo. Isso, pelo que conta, foi um ponto de conflito com o pai mesmo muito depois que Moçambique já tinha se tornado independente: já em Portugal, ele continuou reproduzindo o discurso racista que respaldava sua violência contra os nativos em África. Essa ideologia, aliás, era a mesma que oprimia a ele próprio, ainda que talvez ele não se desse conta disso. Como escreve Isabela Figueiredo em suas memórias:

Convinha muito [...] que o meu pai se levantasse com a aurora para os ir arrancar [os negros] à palhota ou apanhar na estrada, porque alguém tinha que o fazer, e não seria o branco de primeira, com as mãos administrativas com que recebia, no Banco Nacional Ultramarino, o provento que a exploração do trabalho negro rendia, para usufruto de um sistema de que todos hipocritamente dependiam, sustentavam, e com o qual pactuavam, aceitando a ordem das coisas sem a questionar (FIGUEIREDO, 2018, p. 11).

Se, quando escreve sobre o pai, Figueiredo o toma como representante de todo um sistema, ela, no entanto, se sente filha traidora, e declara: "O meu pai tinha a camisa branca e eu, o seu tesouro, a sua vida, sujei-lha de terra para sempre” (FIGUEIREDO, 2018, p. 84).

\section{A MANCHA}

Em $O$ retorno, quando Rui e a família estão no aeroporto junto a inúmeros outros refugiados à espera do voo para Portugal, o adolescente comenta: “[...] tantas pessoas sentadas no chão à nossa volta, não estão preo- 
cupadas com nódoas nas calças, não se importam de chegar à metrópole com nódoas" (CARDOSO, 2013, p. 59).

Dentro da carga narrativa do enredo, esse trecho ganha duplo sentido: os refugiados - que, em Portugal, passam a ser "retornados" - estão aflitos por deixar, o quanto antes, aquela Angola que se tornou um local hostil a eles, por isso "nódoas nas calças" seriam as últimas das preocupações naquele momento. Por outro lado, manchar as mãos e as roupas em terras africanas surge, tanto em $O$ retorno quanto em Caderno de memórias coloniais, como uma aflição constante das mulheres que ali residiam.

A mancha representa um contraste entre a civilização portuguesa e a suposta "selvageria" nativa. Como escreve Isabela Figueiredo: "Não havia forma de poupar o meu corpo às manchas da terra, contudo estava proibida de me manchar dela. Não havia forma de me libertarem dessa necessidade de me manter imaculadamente branca" (FIGUEIREDO, 2018, p. 125).

Em Caderno de memórias coloniais, Isabela comenta a obsessão de sua mãe em vesti-la de branco, mesmo que a possibilidade de sujar a roupa na poeira vermelha de Moçambique fosse imensa, ainda mais para uma criança. Às esposas e mães portuguesas residentes nas "províncias ultramarinas" cabia o zelo constante à aparência dos filhos e do marido; uma roupa manchada, mais do que sinal de descuido doméstico, era sinônimo de assimilação à (o que entendiam como) incivilidade africana. Em uma sociedade colonialista e patriarcal, ambas as ideias seriam inaceitáveis. Por isso apenas a gravidade da situação é que justifica o descuido da mãe de Rui no aeroporto, em $O$ retorno:

A mãe nem sequer dá conta que a minha irmã com o vestido azul clarinho que trouxe, que má ideia trazer um vestido azul clarinho, a mãe nem sequer dá conta que a minha irmã está sentada no chão, encostada à parede, os caracóis louros desmanchados contra a parede, uma rapariga tem de ter ainda mais cuidado do que um rapaz, tem de se comportar de outra maneira, se uma rapariga fica falada ninguém a quer (CARDOSO, 2013, p. 60).

Também as roupas da Isabela menina precisavam ser claras e imaculadas: "[...] me vestiam sempre de branco, como um cordeiro que há de sacrificar-se" (FIGUEIREDO, 2018, p. 92). Igualmente, as roupas de seu pai: no Caderno, há um capítulo que se inicia com a sentença "As camisas do meu pai eram sempre brancas" (FIGUEIREDO, 2018, p. 81). É, não por acaso, o capítulo em que a narradora descreve o momento em que percebeu que aprendera a ler. Ela descreve esse momento de percepção - quando, passeando de carro com seu pai, deu-se consigo mesma podendo ler anúncios publicitários - como uma tangerina madura que havia se aberto em seu cérebro. É essa tangerina madura, sumarenta, que vai manchar a camisa de seu pai. Metonimicamente, aquela primeira percepção de alfabetização já continha, em si, a escrita que permitiria a existência do Caderno de memórias coloniais. A escrita surge, então, em seu caráter ambíguo: tanto é fruto da 
civilização quanto é aquilo que vai denunciar seu lado mais atroz. Escrita é mancha, é mácula do ideal, da perfeição. É simbólico, nesse capítulo, a pequena marca de caneta estourada no bolso da camisa do pai:

O meu pai vestia uma camisa de algodão fino, muito branca. Lavadinha, passada a ferro com zelo pela minha mãe, apertada demais no botão da barriga, quase a esgarçar. A pele do meu pai, tostada, brilhava de brilho. E os olhos, de brilho. O sorriso do meu pai sorria sozinho. Sem nada mais escondido. À noite chegaria a casa com a camisa negra de nódoas, porque o meu pai tocava e deixava tocar-se pelo pó, pelo carvão, pelas laranjas, por mim. Agora estava impecável. No bolso da camisa notava-se um resto de nódoa a tinta de caneta rebentada. Coisa de nada. Um milímetro. Impecável (FIGUEIREDO, 2018, p. 82).

"Esse milagre de ler, essa magia tão rápida no meu cérebro, como se alguém movesse uma varinha à distância ou soletrasse palavras misteriosas, desenfeitiçaram-me" (FIGUEIREDO, 2018, p. 82), narra Isabela Figueiredo pouco adiante. O fim do encantamento é o começo da consciência problematizadora da menina que aprendia a ler. Vem disso que a narradora entenda que, a partir desse episódio, se tornaria, de certo modo, inimiga do pai que tanto amava. Com a aquisição da leitura vem também a leitura crítica de mundo, e a consciência da desigualdade racial, social e de gênero existente no sistema colonial. Tudo o que presenciou surgiria como acusação no $\mathrm{Ca}$ derno de memórias coloniais, isto é, denúncia das violências as mais diversas, por parte de muitos colonos, contra os nativos africanos: abusos físicos, subalternização, precarização, humilhação, segregacionismo. A mancha da caneta denunciadora é a mancha do próprio colonialismo. É seu sangue.

Antes disso, porém - antes do momento em que o colonialismo pudesse ser visto como mancha, como vergonha -, a representação da mancha vem enquanto contraste entre a sociedade portuguesa e as culturas e ambiente nativos.

Para além de $O$ retorno, há um conto de Dulce Maria Cardoso em que isso também fica claro. No conto "O coração do meu mundo ou o papagaio que gostava de bolos de arroz", da coletânea Tudo são histórias de amor (publicado pela Tinta-da-china Brasil em 20177), Dulce Cardoso usa da primeira pessoa e do nome próprio para narrar algumas memórias de infância. Dentre essas, ela se lembra da imagem de uma santa que a mãe mantinha no quarto, o Imaculado Coração, na qual ela não podia tocar porque suas mãos poderiam sujá-la: "Não podia tocar no Imaculado Coração, não fossem as minhas mãos sujas de esgravatar tesouros no nosso quintal e nos quintais vizinhos sujar o manto branco que cobria a Virgem" (CARDOSO, 2017, p. 212). A liberdade dos homens em terras africanas, que permitia que transitassem despudoramente nas estradas de pó vermelho, assim como a liberdade das crianças brincando, inocentes, em seus quintais, fazia com que esses homens e crianças sempre estivessem, ao menos aos olhos das mulheres 
brancas, sujos. Sempre estariam sujas as roupas de Isabela e de seu pai, bem como as mãos da Dulce Cardoso menina. A sujeira, nesse caso, é a liberdade que as mães e esposas, presas aos afazeres domésticos, não tinham. Ao mesmo tempo, era preciso preservar seus maridos e crianças dessa liberdade, dessa sujeira que ia contra o que tinham como ideal de moral e civilização.

Em Caderno de memórias coloniais, Figueiredo narra que, mesmo quando seus pais estavam levando-a para embarcar no avião que a conduziria ao refúgio em Portugal, era uma prerrogativa que ela e seu pai não se sujassem:

Subi para a carrinha com ordem para não me sujar; não que ma tenham dado - eu sabia - não podia sujar-me nunca: tinha esgotado a prerrogativa ao nascer. Sujava-me muito, primeiro que tudo, prioritariamente. Nisso, eu e ele éramos iguais. Íamos com a terra. Estávamos envolvidos nela, resolutamente (FIGUEIREDO, 2018, p. 122).

Aqui, as manchas da terra africana ainda a unem a seu pai: eles se identificam profundamente entre si e com Moçambique - ele porque teria ajudado a construi-la, ela porque já nascera nesse país.

É a partir da consciência da situação de refúgio, no caso de $O$ retorno, ou da consciência do horror da colonização, no caso de Caderno de memórias coloniais, que a mancha passa a marcar os próprios retornados enquanto diferentes, não-pertencentes. Enquanto desterrados:

Os desterrados são pessoas que não puderam regressar ao local onde nasceram, que com ele cortaram os vínculos legais, não os afetivos. São indesejados nas terras onde nasceram, porque a sua presença traz más recordações. Na terra onde nasci seria a filha do colono. Pesaria sobre mim essa mancha. À mais que provável retaliação. Mas a terra onde nasci existe em mim como uma nódoa de caju, impossível de disfarçar (FIGUEIREDO, 2018, p. 166).

Aqui, Isabela Figueiredo se refere à impossibilidade de retorno a Moçambique. Não seria bem-vinda. Os retornados, porém, também não foram bem-vindos em Portugal: “[...] os de cá gostam menos de nós do que os pretos de lá" (CARDOSO, 2013, p. 219), diz Rui em O retorno. $\mathrm{Na}$ entrevista a Alleid, Dulce Cardoso diz:

Não foi a metrópole que quis que os retornados voltassem, os retornados quiseram voltar, então, de alguma forma, cada retornado apagou de si as marcas, as cicatrizes do que foi e recomeçou como fosse de cá. De alguma forma, nós abdicamos de nossa identidade enquanto grupo para nos diluirmos (CARDOSO, 2014, p. 121).

As “[...] marcas, as cicatrizes" (CARDOSO, 2014, p. 121), asnódoas. Se em terras africanas os ex-colonos se tornaram alvo de vingança, em Portugal, eram alvo de acusações, exclusões, piadas, humilhação, descaso. Escreve Isabela Figueiredo: 
Eu tinha andado a roubar os pretos. Julgava que me iam lavar pezinhos com água de rosas?!

Isto não eram as Áfricas!

"Ah, não gostas de bofe com arroz? Andaste a roubar os pretos e julgas que havemos de te servir camarão num prato de ouro!"

Não se responde. Baixa-se os olhos. É mentira e é verdade, mas ambas precisam de voz, e não a temos. É muito cedo. Eu ainda estava na raiz da verdade. Ainda lá dentro, húmida, crescendo, comendo terra, esperando terra (FIGUEIREDO, 2018, p. 136).

Sobre a voz dos retornados que Isabela Figueiredo, no trecho, afirma que não tinham, Cardoso comenta na entrevista:

[...] o que acontece é que estas pessoas raramente têm voz. A história é contada por quem tem voz, e o poder é de quem tem voz, assim como as decisões são dos que têm voz. Veja, os hotéis aqui de Lisboa, do Estoril, em 75, estiveram cheios de retornados, de refugiados. Eu já estive lá e eu não conheço ninguém. Eu não conheço ninguém que diga que tenha lá estado. Ninguém fala sobre o assunto. Por quê? Houve milhares de pessoas que estiveram nessa situação. As pessoas têm vergonha, com isso não há registro (CARDOSO, 2014, p. 104).

E Figueiredo, no Caderno, explica sobre a voz inerente a cada memória particular:

Todos os lados possuem uma verdade indesmentível. Nada a fazer. Presos na sua certeza absoluta, nenhum admitirá a mentira que edificou para caminhar sem culpa, para conseguir dormir, acordar, comer, trabalhar. Para continuar. Há inocentes-inocentes e inocentes-culpados. Há tantas vítimas entre os inocentes-inocentes como entre os inocentes-culpados. Há vítimas-vítimas e vítimas-culpadas. Entre as vítimas há carrascos (FIGUEIREDO, 2018, p. 136).

Entre inocentes e culpados, as manchas são os resíduos do colonialismo: "Um branco que viveu o colonialismo será um branco que viveu o colonialismo até o dia da morte" (FIGUEIREDO, 2018, p. 165). Ao mesmo tempo, sendo essas manchas um sinal de não-pertencimento, de contraste, são, também, um componente da identidade dos retornados. Desse modo, essas escritoras retornadas releem as próprias memórias - e, em consequência, a própria identidade - a partir da "mancha do colonialismo", entendendo que a ideologia colonial influenciava as atitudes de todos que nela estavam, de algum modo, inseridos. Eliana Tolentino escreve, em "Retorno e retornados - um não lugar, um não estar", que:

Essa nova geração de portugueses aponta para a consciência do papel da colonização. Em várias áreas, essa geração de herdeiros de uma memória que os faz se envergonhar de seu país vem escrevendo sobre os de lá, os de cá e os que de lá voltaram após a "descolonização." O pós-74 resultou numa produção 
literária significativa e para Eduardo Lourenço era $\otimes$ Como se nesse momento, quer dizer, depois de 75 , entre 75 e 80, em Portugal, a consciência portuguesa, a imaginação portuguesa, o imaginário português quisessem desenhar um outro mapa. (LOURENÇO, 2004, p. 349) (TOLENTINO, 2017, p. 6051).

\section{CONSIDERAÇÕES FINAIS}

A partir da releitura que fazem Isabela Figueiredo e Dulce Maria Cardoso do processo de descolonização de Moçambique e Angola, tentamos, por nossa vez, ler como em Caderno de memórias coloniais e em O retorno a representação da mancha, em suas várias possiblidades, surge como símbolo importante.

Neste artigo, a mancha pôde ser vista, em uma das suas representações, como contraste entre o ideal de moral e civilidade dos portugueses que foram morar em África e aquilo que desprezavam enquanto nativo, "selvagem"(e libertador, como também se demonstrou). Mais especificamente, mostrou-se como as mulheres brancas colonas zelavam por manter nítidas as fronteiras entre portugueses e africanos, e isso começava pela sua fidelidade ao patriarcado do qual, na verdade, eram vítimas. Como comenta Paulina Chiziane no prefácio ao Caderno de Memórias coloniais:

A voz da Isabela Figueiredo emerge em protesto contra este machismo do sistema colonial, que não reconhece a dinâmica das relações de género, que a sociedade colonial construiu entre os homens e as mulheres. Só fala de batalhas, vitórias e tretas dos homens. A mulher branca é invisível, é silenciada, demonstrando desta forma que as mulheres brancas são as principais vítimas da violência do colonialismo, mesmo antes dos negros. A mulher branca não tinha voz, tal como todos os pretos e pretas. Não era autorizada a falar alto, mesmo dentro de casa ou no círculo dos amigos. Elas não tinham direito à sua própria sexualidade, tinha que ter o sexo estreito e casto, tal como os colonizados que não tinham direito à sua terra $\mathrm{e}$ à sua liberdade. Elas não tinham o mesmo direito de escolher os parceiros sexuais e seriam excomungadas do grupo se se envolvessem com um negro, tal como os negros não tinham voz nem o direito de viver, tal como bem descreve a autora: morrer sempre foi fácil naquela terra, antes ou depois (CHIZIANE, 2018, p. 16, grifo da autora).

A noção da mancha enquanto contraste entre Portugal e as colônias africanas também funciona por sua via inversa, isto é: se antes os colonos tinham as manchas de sujeira das roupas e das mãos enquanto mácula em terras africanas, em Portugal eles eram vistos por aqueles que não saíram de terras portuguesas enquanto "manchados", "maculados" por terem, conforme as acusações, "explorado os negros africanos" (cf. CARDOSO, 2013, p. 129; FIGUEIREDO, 2018, p. 136; PERALTA, 2018, p. 147). A ambiguidade da mancha é, aqui, o próprio caráter de verdade simultâneo ao de não verdade da acusação (FIGUEIREDO, 2018, p. 136); a história não se constrói entre bons 
e maus, sem nuances. Muitos dos que acusavam os retornados de racismo em África eram racistas em Portugal e continuaram a sê-lo muito tempo depois, por isso a importância do trabalho de releitura, reflexão e denúncia que vem fazendo a geração de escritores retornados. Como comenta Dulce Cardoso:

Nunca resolvemos a questão do colonialismo, nem a questão do pós-colonialismo. Nunca resolvemos nada. É só para o que nos convém. É só para nos culparmos uns aos outros. Só que isso não é resolver. Perguntam-me, por exemplo, "então, afinal, houve racismo em Angola?" e eu respondo: "como é que não poderia haver racismo em Angola, se em 2013 há racismo em Lisboa? Como é que em Angola, numa colônia, não haveria? Em 1974 não havia racismo? É claro que havia racismo". Agora, eu já não estou preocupada que em 74 havia racismo, mas que em 2013 continua a haver racismo. Se em 74 ou 75 tivéssemos tido consciência que havia racismo talvez agora em 2013 não houvesse tanto. Então, não resolvendo essas questões, o racismo continua. Temos medo do que é diferente. Temos medo de tudo o que é desconhecido. Uma cor de pele, uma conduta diferente, tornam-se assustadores. Se até do igual temos medo, do que dirá do que é-nos diferente? (CARDOSO, 2014, p. 107-108).

Esse trabalho de releitura, reflexão e denúncia é também, em outra representação da mancha, e como se demonstrou neste texto, a mancha do passado dos retornados que não reconhecem o lado sombrio da colonização. Que não reconhecem quão necessário foi o processo descolonizador. Parte disso que Isabela Figueiredo se diga traidora da memória do pai e Dulce Maria Cardoso afirme que muitos retornados a considerem traidora (CARDOSO, 2021b). Escrita também é mancha. Diz Isabela Figueiredo que "A verdade era uma história muito longa e complexa, rica de narrativas encaixadas alternadas, simultâneas, polifônica" (FIGUEIREDO, 2018, p. 150). Essas autoras escolhem, conscientemente, manchar a memória que vangloria os salazaristas.

Ao mesmo tempo em que mancham, que contam, que reescrevem, também se reconhecem "manchadas", marcadas: são retornadas, afinal. Têm em si esse processo identitário do contraste, da não-pertença. Conforme expõe Tania Mara Antonietti Lopes em "Vestígios da memória e regressos em Isabela Figueiredo e Dulce Maria Cardoso":

Ainda subsistem rastros da memória colonial. A partir dessas narrativas que mencionamos, torna-se necessário saber quem são e o que dizem os sujeitos marginalizados pela ordem colonial-patriarcal que colocam em discussão. Esses sujeitos [os escritores retornados] se manifestam na forma do relato de memória, seja ela primária ou secundária (como preferimos classificar), para construir uma nova narrativa (LOPES, 2019, p. 281).

As manchas, em suma, são os resíduos do colonialismo estampadas em qualquer um que o tenha vivido. 


\section{REFERÊNCIAS}

CARDOSO, Dulce Maria. O retorno. Rio de Janeiro: Tinta-da-china Brasil, 2013.

. Entrevista - Dulce Maria Cardoso e Júlia Nery: olhares em torno da diáspora portuguesa em França e África. Entrevista concedida a Alleid Ribeiro Machado. Desassossego, FFLCH/USP, n. 12, p. 95-119, dez. 2014. Disponível em: https://www.revistas.usp.br/desassossego/article/view/76210/92474. Acesso em: 27 jul. 2021.

O coração do meu mundo ou o papagaio que gostava de bolos de arroz. In: CARDOSO, Dulce Maria. Tudo são histórias de amor. Rio de Janeiro: Tinta-da-china Brasil, 2017. p. 203-223.

. O coração do meu mundo ou o papagaio que gostava de bolos de arroz. Piauí, 2015. Disponível em: https://piaui.folha.uol.com.br/materia/o-coracao-do-meu-mundoou-o-papagaio-quegostava-de-bolo-de-arroz/. Acesso em: 25 maio 2021a.

"Há retornados que acham que sou uma traidora". Público, 17 set. 2015, Livros. Entrevista concedida a Kathleen Gomes. Disponível em: https://www.publico.pt/2015/09/17/culturaipsilon/noticia/dulce-1708071. Acesso em: 29 maio 2021b.

CHIZIANE, Paulina. Sobre Caderno de memórias coloniais. In: FIGUEIREDO, Isabela. Caderno de memórias coloniais. São Paulo: Todavia, 2018. p. $12-19$

FIGUEIREDO, Isabela. Caderno de memórias coloniais. São Paulo: Todavia, 2018.

NORONHA, Jovita Maria Gerheim (Org). Ensaios sobre a autoficção. Belo Horizonte: Editora UFMG, 2014.

LOPES, Tania Mara Antonietti. Vestígios da memória e regressos em Isabela Figueiredo e Dulce Maria Cardoso. Convergência Lusíada, Rio de Janeiro, n. 42, p. 277-289, 2019. Disponível em: https://convergencialusiada.com.br/ rcl/article/view/352/281. Acesso em 27 jul. 2021.

MIRANDA, Wander de Melo. A ilusão autobiográfica. In: Corpos escritos: Graciliano Ramos e Silviano Santiago. Belo Horizonte: Editora UFMG, 1992, p. 25-41.

PERALTA, Elsa. O testemunho do "retorno": deslocamento, história ilegítima, desidentificação. In: Identidades em trânsito. ALVES, Fernanda Mota; HAMMER, Gerd; LOURENÇO, Patrícia (Org). Lumus: Lisboa, 2018. p. 139-158. Disponível em: https://repositorio.ul.pt/bitstream/10451/35605/1/ IdentidadesEmTransito_DIGITAL-OUT18.pdf. Acesso em 27 jul. 2021.

SAID, Edward. Reflexões sobre o exílio. In: SAID, Edward. Reflexões sobre o exílio e outros ensaios. São Paulo: Companhia das Letras, 2003. p.46-60. 
TOLENTINO, Eliana da Conceição. Retorno e retornados - um não lugar, um não estar. In: XV Congresso Internacional da ABRALIC - textualidades contemporâneas, 2017, Rio de Janeiro. Anais eletrônicos do XV Congresso Internacional da ABRALIC - textualidades contemporâneas, 2017.v. 4. p. 60496059. Disponível em: https://abralic.org.br/anais/arquivos/2017_1522173379. pdf. Acesso em 21 jul. 2021.

Recebido para avaliação em 01/06/2021 Aprovado para publicação em 16/07/2021

\section{NOTAS}

1 Larissa Fonseca e Silva é mestranda em Teoria Literária e Crítica da Cultura, Linha de Pesquisa LMC (Literatura e Memória Cultural) no PROMEL (Programa de Mestrado em Letras da UFSJ), desenvolvendo o projeto de dissertação intitulado "Os ponteiros que nos situam: memória, tédio e identidade no romance Campo de Sangue, de Dulce Maria Cardoso" com o apoio da FAPEMIG. Licenciada em Letras - Língua Portuguesa e suas Literaturas pela UFS (Universidade Federal de São João del-Rei) e graduanda em Letras - Língua Inglesa e suas Literaturas também pela UFSJ. Possui, dentre os interesses de pesquisa, Literaturas Contemporâneas em Língua Portuguesa (especialmente Literatura Portuguesa e de autoria feminina). ORCID: https://orcid.org/0000-0003-4501-9293

2 Eliana da Conceição Tolentino é licenciada em Letras pela Faculdade Dom Bosco de Filosofia, Ciências e Letras (1985), mestre em Estudos Literários: Literatura Brasileira pela Universidade Federal de Minas Gerais (UFMG) (1994), doutora em Estudos Literários: Literatura Comparada pela UFMG (2006) e tem pós-doutorado em Estudos Comparados de Literaturas de Língua Portuguesa pela Universidade de São Paulo (2017). Professora associada da Universidade Federal de São João del-Rei (UFSJ), atua na graduação e na pós-graduação do curso de Letras. ORCID: https://orcid.org/0000-0001-6464-9640

3 À altura da publicação do livro, o blogue se chamava Mundo Perfeito. Atualmente, a autora possui um blogue cujo nome é Novo Mundo. Disponível em: https://novomundoperfeito. blogspot.com/. Acesso em: 31 maio 2021.

4 As teorizações sobre a autoficção a partir de Philippe Lejeune, Serge Doubrovsky e outros teóricos serão intensificadas no Brasil principalmente a partir da publicação de Ensaios sobre a autoficção, coletânea organizada por Jovita Maria Gerheim Noronha, que junto a Maria Inês Coimbra Guedes também traduz os ensaios (cf. NORONHA, 2014). Para este artigo, porém, não nos interessa delimitar se o livro de Isabela Figueiredo se insere no gênero "autobiografia", "autoficção" ou "romance”, e sim reforçar o caráter de indecidibilidade de qualquer relato que se baseie na memória, como é o caso de Caderno de memórias coloniais.

5 Personagem de outro livro da autora, Os meus sentimentos, publicado pela Tinta-da-china Brasil em 2005.

6 A cachorrinha da família de Rui, no livro.

7 O conto também foi publicado na Revista Piauí. Cf: CARDOSO, 2021. 